\title{
MINERALISATON ASSAYS OF SOME ORGANIC RESOURCES OF AQUATIC SYSTEMS
}

\author{
BITAR, A. L. ${ }^{1}$ and BIANCHINI Jr., I. ${ }^{1,2}$ \\ ${ }^{1}$ P. P. G. Ecologia e Recursos Naturais, Universidade Federal de São Carlos, Via Washington Luís, km 235, \\ C. P. 676, CEP 13565-905, São Carlos, SP, Brazil \\ ${ }^{2}$ Departamento de Hidrobiologia, Universidade Federal de São Carlos, Via Washington Luís, km 235, \\ C. P. 676, CEP 13565-905, São Carlos, SP, Brazil \\ Correspondence to: Irineu Bianchini Jr., Departamento de Hidrobiologia, Universidade Federal de São Carlos, Via \\ Washington Luís, km 235, C. P. 676, CEP 13565-905, São Carlos, SP, Brazil, e-mail: irineu@ power.ufscar.br \\ Received March 5, 2002 - Accepted April 4, 2002 - Distributed November 30, 2002
}

(With 2 figures)

\begin{abstract}
Assays were carried out to evaluate the consumption of dissolved oxygen resulting from mineralisation processes in resources usually found in aquatic systems. They were also aimed at estimating the oxygen uptake rate of each investigated process. Experiments were conducted using substrates from 3 different places. A fixed amount of substrate was added to 5 litres of water from Lagoa do Infernão that was previously filtered with glass wool. After adding the substrates the bottles were aired and the amount of dissolved oxygen and the temperature were monitored for 55 days. The occurrence of anaerobic processes was avoided by reoxygenating the bottles. The experimental results were fitted to a first order kinetics model, from which the consumption of dissolved oxygen owing to mineralisation processes was obtained. The amount of oxygen uptake from the mineralisation processes appeared in the following decreasing order: Wolffia sp., Cabomba sp., Lemna sp., DOM (Dissolved Organic Matter), Salvinia sp., Scirpus cubensis, stem, Eichhornia azurea, sediment and humic compounds. The deoxygenation rates (day ${ }^{-1}$ ) were: 0.267 (humic compounds), 0.230 (Lemna sp.), 0.199 (E. azurea), 0.166 (S. cubensis), 0.132 (sediment), 0.126 (DOM), 0.093 (Cabomba sp.), 0.091 (stem), 0.079 (Salvinia sp. and Wolffia sp.). From these results, 2 groups of resources could be identified: the first one consists of detritus with higher amounts of labile (ready to use) compounds, which show a higher global oxygen uptake during the mineralisation process; the second one consists mainly of resources that show refracting characteristics. However, when the consumption rates are analysed it is noted that the mineralised parts of the refracting substrates can be easier to process than the labile fractions of the less refracting resources.
\end{abstract}

Key words: mineralisation, organic matter, kinetics and oxygen uptake.

\section{RESUMO}

Ensaios de mineralização de alguns recursos orgânicos em sistemas aquáticos

Os ensaios visaram avaliar os consumos de oxigênio dissolvido (OD) decorrentes da mineralização de recursos usualmente presentes nos sistemas aquáticos e estimar os coeficientes de utilização de oxigênio dos processos. Para tanto, as amostras dos recursos foram colhidas em 3 locais diferentes. Os ensaios foram preparados a partir da adição de $100 \mathrm{mg}$ (peso seco) de cada tipo de recurso em 5 litros de água da Lagoa do Infernão. Após a adição dos substratos, os frascos foram aerados e durante 55 dias foram determinados os teores de oxigênio dissolvido e a temperatura. A ocorrência de processos anaeróbios foi evitada por meio da reoxigenação periódica dos frascos. Após os ajustes dos resultados a um modelo cinético (de $1 \underline{a}$ ordem), obteve-se a seguinte ordem no que se refere à utilização de OD devido à mineralização: Wolffia sp., Cabomba sp., Lemna sp., MOD, Salvinia sp., Scirpus cubensis, fuste, Eichhornia azurea, sedimento e compostos húmicos. Os valores obtidos para os coeficientes 
de consumo ( $\mathrm{dia}^{-1}$ ) foram: 0,267 (compostos húmicos), 0,230 (Lemna sp.), 0,199 (E. azurea), 0,166 (S. cubensis), 0,132 (sedimento), 0,126 (MOD), 0,093 (Cabomba sp.), 0,091 (fuste), 0,079 (Salvinia sp. e Wolffia sp.). Com base nesses resultados identificaram-se 2 grupos de recursos, o primeiro constituído por detritos com maior quantidade de compostos lábeis, que apresentam maior consumo global de oxigênio durante a mineralização, e o segundo grupo constituído por detritos com características refratárias. No entanto, ao considerar os coeficientes de consumo verificou-se que as porções mineralizadas dos substratos tidos como refratários podem ser mais facilmente processadas que as frações lábeis dos recursos menos refratários.

Palavras-chave: mineralização, matéria orgânica, cinética e consumo de oxigênio.

\section{INTRODUCTION}

The flow of nutrients and carbon in aquatic systems depends on the way their input and output functions vary with time. In ecosystems these fluxes depend upon the pathways through which the processes of uptake of elements and decay of organic resources take place. The rates at which nutrients and carbon are cycled and accumulated depend mainly on the balance between the immobilisation and mineralisation processes. By immobilisation of a given element or carbon it is meant the incorporation or maintenance in the organic form of such an element. In aquatic systems this process generally occurs due to the action of communities of phytoplanktonic and microorganisms, by absorption into the roots of aquatic plants and by chemical interactions involving humic substances and adsorption processes. Mineralisation occurs when inorganic forms of a given element are released during the catabolism of a resource (e.g. $\mathrm{SO}_{4}^{2-}, \mathrm{CO}_{2}, \mathrm{NH}_{3}$, etc.). The availability of a specific nutrient element therefore depends on the net mineralisation, i.e. the extent to which the mineralisation process exceeds the immobilisation process (Swift et al., 1979). Together with leaching these mechanisms constitute what is known as decomposition processes.

The decay of a given organic resource may be done in an aerobic or anaerobic environment. It is usually acknowledged in kinetics studies that the disappearance of substrates is proportional to the formation of products. For aerobic processes, it is further assumed that the formation of products such as $\mathrm{CO}_{2}$ is also proportional to the oxygen uptake, just like in chemical reactions and stoichiometric relations usually taken as the basis for the process of formation and oxidation of organic resources (Jørgensen, 1986; Chapra \& Reckhow, 1983; Stumm \& Morgan, 1981).

Laboratory assays based upon the degradation of several simple organic compounds (e.g. glucose, glycerol, lactic acid) have demonstrated that the microbial biomass yield is around $48 \%$, even though a wide range of yields were observed depending on the substrate (from 26\% to 88\%) (Ramanathan \& Gaudy, 1972). In quick experiments (lasting 16 days) on glucose decay and $\mathrm{CO}_{2}$ formation, it is estimated that mineralisation is responsible for about $20 \%$ of the used organic carbon, while the remaining carbon is immobilised through the formation of microbial biomass (60\%) and the humification process (20\%) (Antonio, 1992). These aspects are highly relevant for studies on the correlation between organic matter and dissolved oxygen in aquatic systems.

The present study is aimed at discussing issues involved in the mineralisation of some resources usually found in aquatic systems (aquatic plants, dissolved organic matter, sediment, vegetation previously drowned stem and humic substances) using the kinetics of oxygen uptake. It is also aimed at estimating the uptake oxygen rates for each process described.

\section{MATERIALS AND METHODS}

Assays were carried out using 10 samples collected from organic resources from 3 different locations: 1. Lagoa do Infernão $\left(21^{\circ} 35^{\prime} \mathrm{S}\right.$ and $47^{\circ}$ 51'W): Salvinia sp., Scirpus cubensis, Eichhornia azurea, Cabomba sp., sediment, dissolved organic matter (DOM) and total dissolved humic substances (TDHS); 2. reservoir of the UFSCar Campus: drowned stems of bushes; and 3. water tanks of the Hydrobiology and Aquiculture Station at Salto Grande, SP (CESP): Wolffia sp. and Lemna sp. 
The substrates were taken to the laboratory where they were washed in tap water, distilled water and later dried at $60^{\circ} \mathrm{C}$, up to a constant weight. The total humic compounds were extracted from a concentrated 21 litres water sample (from Lagoa do Infernão), by raising the $\mathrm{pH}$, centrifugation and freeze drying, following standard procedures (Stevenson, 1982; Thurman, 1985). The inorganic compounds from the freeze-dried material were then estimated by a thermogravimetric analysis. $100 \mathrm{mg}$ (dry weight) of each kind of substrate were added to 5 litres of water from Lagoa do Infernão that had been filtered in glass wool. For the bottle containing sediment, $300 \mathrm{mg}$ (fresh weight) were added. After adding the substrates, the bottles were aired for 1 hour. The amount of dissolved oxygen (DO) and the temperature were then monitored by an oxymeter during 55 days. The temperature over the whole period was found to lie in the range of $25.7^{\circ} \mathrm{C} \pm$ $2^{\circ} \mathrm{C}$. When necessary anaerobic processes were avoided by reoxygenating the bottles.

\section{RESULTS AND DISCUSSION}

Table 1 shows the evolution of the amount of dissolved oxygen (DO) in the different resources investigated over the period of 55 days. There are two values for the fifth day which corresponds to the date when the bottles were reaired. An intense consumption of DO can be noted in the first days of monitoring, but there is also an increase in the amount of DO in the final stages of the experiments. Because the oxygen used in the DOM mineralisation process is common to all samples and can therefore be considered as a background value, it was subtracted from the values quoted in Table 1 . The time evolution of oxygen uptake is obtained from the integration

TABLE 1

Time evolution of the amounts of dissolved oxygen $(\mathrm{mg} / \mathrm{L})$ in the bottles, for the mineralisation process of various resources.

\begin{tabular}{|c|c|c|c|c|c|c|c|c|c|c|}
\hline $\begin{array}{c}\text { Time } \\
\text { (days) }\end{array}$ & DOM & TDHS & $\begin{array}{c}\text { Lemna } \\
\text { sp. }\end{array}$ & $\begin{array}{c}\text { Wolffia } \\
\text { sp. }\end{array}$ & Sediment & Stem & $\begin{array}{l}\text { Scirpus } \\
\text { cubensis }\end{array}$ & E. azurea & $\begin{array}{c}\text { Cabomba } \\
\text { sp. }\end{array}$ & $\begin{array}{l}\text { Salvinia } \\
\text { sp. }\end{array}$ \\
\hline 0 & 7.52 & 7.52 & 7.52 & 7.38 & 7.45 & 7.38 & 7.38 & 7.52 & 7.52 & 7.52 \\
\hline 1 & 6.7 & 6.2 & 5.18 & 5.2 & 6.02 & 6.52 & 5.75 & 5.95 & 6.44 & 6.96 \\
\hline 2 & 6 & 5.03 & 4.3 & 3.97 & 5.35 & 5.24 & 4.6 & 5.1 & 5.14 & 6.12 \\
\hline 3 & 6.32 & 5.1 & 4.1 & 3.32 & 5.4 & 5.2 & 5.15 & 4.65 & 4.1 & 5.95 \\
\hline 4 & 6.2 & 5.1 & 3.7 & 3.17 & 5.57 & 5.52 & 4.8 & 4.75 & 5 & 5.62 \\
\hline \multirow[t]{2}{*}{5} & 6.12 & 4.8 & 3.9 & 3.84 & 5.32 & 5.2 & 4.93 & 5.05 & 5.2 & 6.02 \\
\hline & 7.38 & 7.38 & 7.38 & 7.38 & 7.38 & 7.38 & 7.38 & 7.38 & 7.38 & 7.38 \\
\hline 6 & 6.4 & 5.9 & 5.3 & 5.6 & 5.4 & 5.9 & 5.4 & 5.5 & 5.8 & 6.4 \\
\hline 7 & 6.27 & 5.6 & 4.82 & 4.75 & 5.68 & 5.62 & 5.52 & 5.77 & 5.7 & 6.32 \\
\hline 11 & 5.9 & 5.38 & 3.4 & 3.5 & 5.48 & 5.4 & 5.2 & 4.82 & 4.62 & 5.6 \\
\hline 12 & 5.77 & 5.05 & 3.61 & 3.15 & 4.64 & 5.07 & 4 & 4.62 & 5.07 & 5.89 \\
\hline 13 & 5.61 & 4.2 & 3.7 & 2.97 & 4.4 & 4.99 & 4.06 & 4.57 & 4.74 & 5.5 \\
\hline 14 & 4.78 & 4.56 & 4 & 3.08 & 4.67 & 5 & 4.35 & 4.34 & 4.76 & 5.65 \\
\hline 17 & 5.77 & 4.71 & 4.19 & 3.52 & 4.96 & 4.61 & 4.36 & 4.53 & 4.58 & 5.3 \\
\hline 20 & 5.96 & 4.98 & 3.77 & 2.99 & 4.75 & 4.42 & 4.3 & 4.4 & 4.55 & 5.59 \\
\hline 24 & 5.66 & 4.71 & 4.1 & 3.65 & 4.94 & 4.39 & 4.04 & 4.31 & 4.16 & 5.68 \\
\hline 31 & 5.72 & 4.67 & 4.31 & 4.69 & 4.94 & 4.76 & 4.96 & 5.19 & 4.58 & 6.03 \\
\hline 33 & 5.33 & 4.79 & 4.6 & 4.42 & 4.67 & 4.83 & 4.27 & 4.98 & 5.22 & 5.84 \\
\hline 41 & 5.7 & 4.47 & 4.86 & 5.13 & 4.73 & 5.2 & 4.54 & 4.94 & 4.77 & 5.17 \\
\hline 55 & 6.59 & 4.67 & 5.62 & 5.96 & 5.08 & 4.89 & 4.95 & 5.04 & 5.8 & 6.4 \\
\hline
\end{tabular}



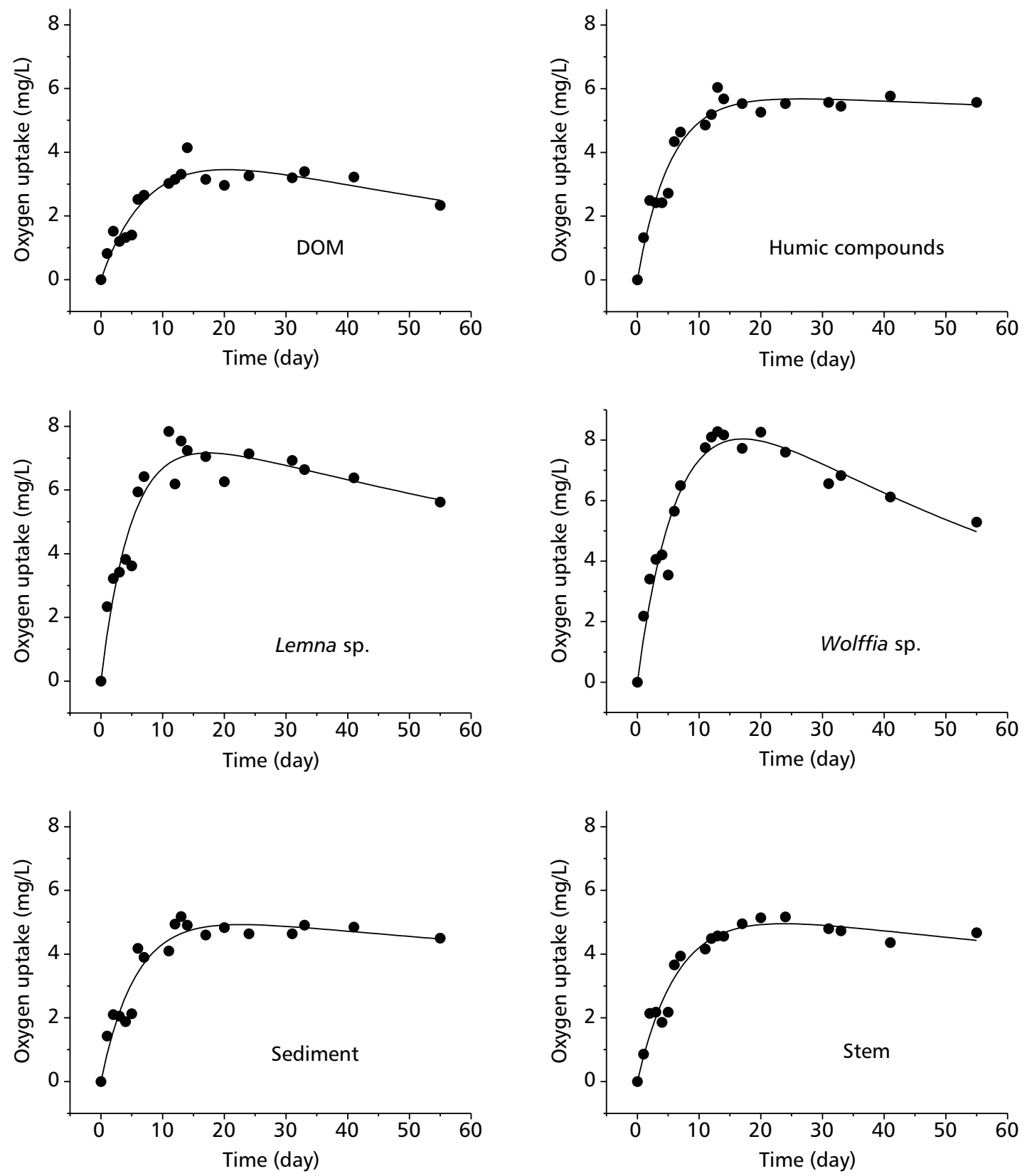

Fig. 1 - Oxygen uptake during the mineralisation of DOM, humic compounds, Lemna sp., Wolffia sp., sediment and stem samples. 

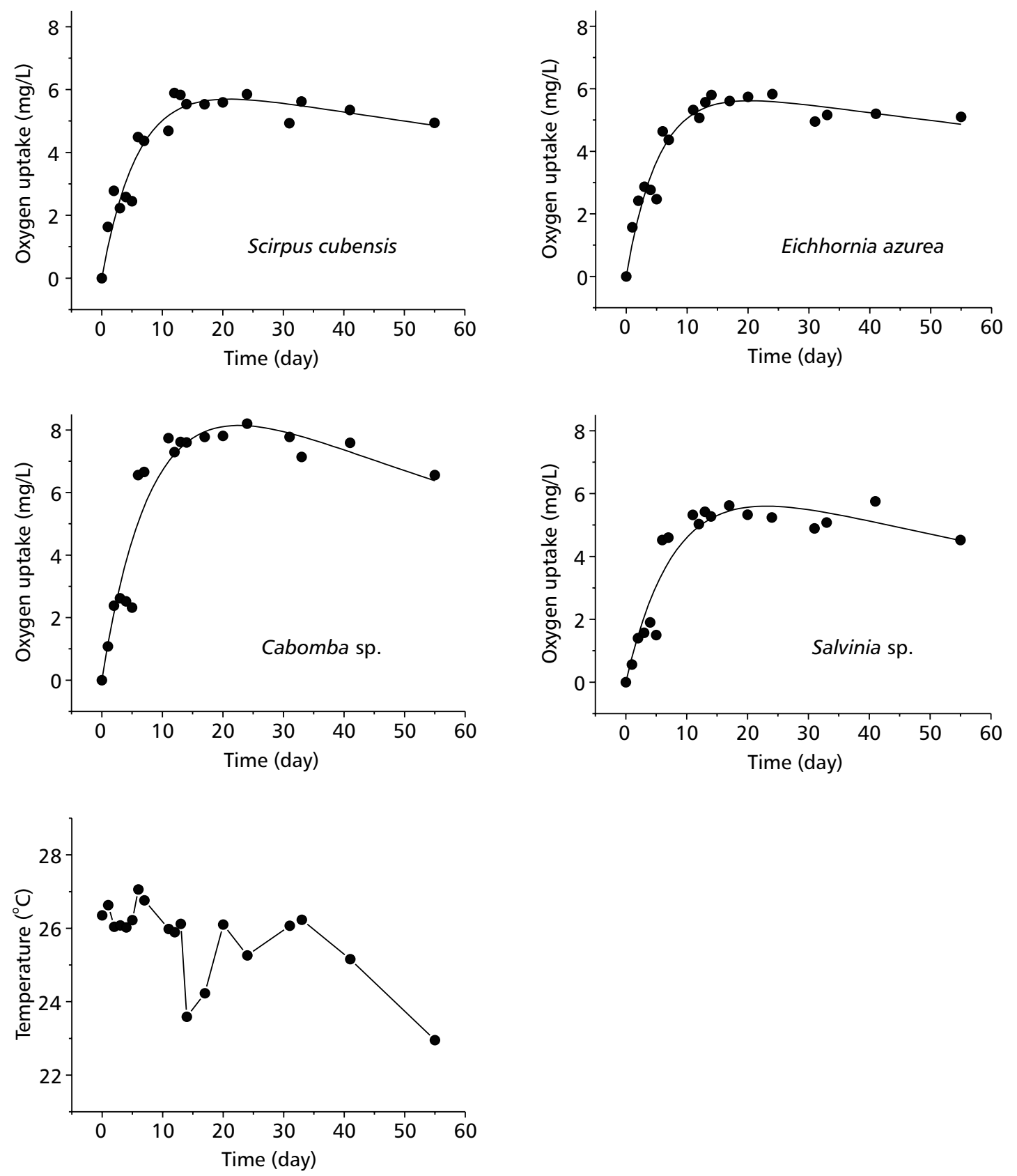

Fig. 2 - Oxygen uptake during the mineralisation of S. cubensis, E. azurea, Cabomba sp. and Salvinia sp. Also shown is the time evolution of the temperature. 
of the use of DO results. This is shown in Figs. 1 and 2 for the various resources.

The results were fitted to a $1^{\text {st }}$ order kinetics model, similar to the one used to describe BOD tests. However, since there was no control over possible oxygenation owing to reairing processes occurring during the time period of the experiments, an additional term was incorporated into the equation. It must be stressed that these reairing processes do not refer to the controlled reairing procedured adopted in the fifth day of the experiments. The analytic integration of the differential equations resulted in a model (Equation 1), similar to the classic one proposed by Streeter \& Phelps (1925).

$$
\mathrm{OC}=\mathrm{L} \times \frac{\mathrm{k}_{1}}{\mathrm{k}_{2}-\mathrm{k}_{1}} \times\left(\mathrm{e}^{-k_{1} t}-\mathrm{e}^{-k_{2} t}\right)
$$

where:

$\mathrm{OC}=$ the change in oxygen concentration per unit of time, $\mathrm{mg} / \mathrm{L}$

$\mathrm{L}=$ total oxygen consumption, $\mathrm{mg} / \mathrm{L}$

$\mathrm{k}_{1}=$ deoxygenation rate constant, day $^{-1}$

$\mathrm{k}_{2}=$ reaeration rate constant, day ${ }^{-1}$

The coefficients (consumption and reaeration rates, total oxygen consumption and R-squared) deriving from the fitting procedure are shown in Table 2. Even though equivalent amounts of substrate were added, there were differences in the quantities of oxygen involved in the mineralisation processes as well as in the deoxygenation rates. From these results it is possible to establish the following order for decreasing amounts of used DO in the mineralisation processes (L): Wolffia sp., Cabomba sp., Lemna sp., DOM, Salvinia sp., S. cubensis, stem, E. azurea, sediment, and TDHS. The obtained results for the consumption rates $\left(\mathrm{k}_{1}\right)$ define the following order: TDHS, Lemna sp., E. azurea, S. cubensis, sediment, DOM, Cabomba sp., Salvinia sp., and Wolffia sp.

Using the approximation that the stoichiometry of oxidation reactions of organic resources are analogous to those of glucose and that the amount of organic carbon of the detritus is around $47 \%$ of its biomass (ash free basis), it is estimated that $42.3 \mathrm{mg}$ of detrital organic carbon were added to each reaction bottle. These approximations are similar to the ones proposed by Westlake (1963),
Wetzel (1983) and Davis \& Cornwell (1991). A theoretical value for the DO demand is then 114 $\mathrm{mg}$, or $22.8 \mathrm{mg} / \mathrm{L}$. When the theoretical value is compared to the experimental results of Table 2 , one notes that during the assays the oxidation processes stabilised at values that varied from $10 \%$ to $50 \%$ of the estimated values. These data provide an indication of the global mineralisation level of the resources.

Considering that the experiments take only 55 days, it is also possible to infer that $48 \%$ of the carbon has probably been converted into microbial biomass through the immobilisation process. This agrees with the average results described by Ramanathan \& Gaudy Jr. (1972). The consumption of oxygen during the mineralisation of Wolffia sp. and Cabomba sp. corresponds to $97 \%$ and $57 \%$, respectively, of the theoretically estimated demand. For these resources, therefore, oxidative processes rather than humification occurred.

For the other resources the uptake processes stabilized at values between $18 \%$ and $39 \%$ of the estimated demand. Hence, for DOM, humic compounds, Lemna sp., sediment samples, stem, S. cubensis, E. azurea and Salvinia sp. the decomposition processes favoured the formation of humic compounds. As the samples were heterogeneous, it is believed that oxidation occurred predominantly in the labile portions (ready to use). For aquatic macrophytes these portions correspond to the protoplasmic fractions and not to structural elements (cellulose, lignin, etc.).

Since the organic resources under investigation result from decomposition processes, it is expected that the humic compounds should have a higher level of organic carbon than the remaining ones. One should therefore expect higher values for the theoretical oxygen demand and oxygen uptake. However, refracting properties must also be considered. For instance, it is worth noting the high amount of deoxygenation in the mineralisation process of these compounds. This indicates that there existed humic compound fractions that consisted of ready-to-oxidize forms, even if in a small quantity. Considering that these compounds are present in large quantities in aquatic systems, their importance - from an energetic point of view - should be highlighted for the survival of microbial communities. 
TABLE 2

Parameters obtained by fitting the experimental results to the kinetic model of Equation 1.

\begin{tabular}{|l|c|c|c|c|}
\hline \multicolumn{1}{|c|}{ Resources } & $\begin{array}{c}\mathbf{L} \\
(\mathbf{m g} / \mathbf{L})\end{array}$ & $\begin{array}{c}\mathbf{k}_{\mathbf{1}} \\
\left(\mathbf{d a y}^{-\mathbf{1}}\right)\end{array}$ & $\begin{array}{c}\mathbf{k}_{\mathbf{2}} \\
\left(\mathbf{d a y}^{\mathbf{- 1}}\right)\end{array}$ & $\mathbf{r}^{\mathbf{2}}$ \\
\hline Dissolved organic matter & 4.44 & 0.126 & 0.0123 & 0.88 \\
\hline Humic compounds & 2.09 & 0.267 & 0.0159 & 0.94 \\
\hline Lemna sp. & 4.60 & 0.230 & 0.0253 & 0.91 \\
\hline Wolffia sp. & 11.47 & 0.079 & 0.0743 & 0.94 \\
\hline Sediment & 2.53 & 0.132 & 0.0800 & 0.91 \\
\hline Drowned stems of bushes & 2.81 & 0.091 & 0.0885 & 0.95 \\
\hline Scirpus cubensis & 2.88 & 0.166 & 0.0376 & 0.90 \\
\hline Eichhornia azurea & 2.80 & 0.199 & 0.0380 & 0.93 \\
\hline Cabomba sp. & 6.84 & 0.093 & 0.0288 & 0.91 \\
\hline Salvinia sp. & 3.70 & 0.079 & 0.0623 & 0.90 \\
\hline
\end{tabular}

It can be demonstrated that the available energy of DOM is higher than for the humic compounds, by comparing the accumulated uptakes of DO (L) from the mineralisation processes. When the deoxygenating rates are also taken into account, however, it is seen that the deoxygenating processes from the labile fractions of humic compounds appear to create an oxygen uptake rate that is 2.1 higher than for the dissolved organic compounds.

Among the ten substrates investigated, the aquatic macrophytes detritus constitute the group that tended to consume the largest quantity of oxygen. This probably reflects their important role in maintaining heterotrophic communities and in keeping the balance of DO in aquatic systems. In this context, the senescent temporal functions of these organisms become extremely important. In particular because, together with a function for the input of detritus, they may form a basis for creating a model that describes the time evolution of the dissolved oxygen depletion.

As for the remaining refracting compounds (organic matter from sediment and stem), it may be suggested that their higher carbon levels compared to the other detritus - created an oxygen demand that ended up leveling, in practice, the ones observed for the macrophytes. For the mineralisation processes of these substrates, one must also consider the possible presence of nutrients (e.g. attached nitrogen) that could favour oxidative processes.
The method adopted here could have caused the uptake rates and the total amount of oxygen involved in the mineralisation to be underestimated, if the natural reairing processes were not taken into account. Under the experimental conditions adopted there was a mean reairing of $4 \%$ per day, which in some cases could cause variations from $1.2 \%$ to $8.8 \%$. It is believed that the process of reoxygenation occurred mostly because of the lowering of temperature in the bottles illustrated in Fig. 2. This decrease caused a higher oxygen solubility in addition to a higher demand from the mineralisation processes.

In summary, the results described suggest that the amount of oxygen uptake in mineralisation processes seems to be tied basically to the amount of labile compounds in the organic resources. The deoxygenation rates, though, appear to depend also on the chemical composition of the labile compounds.

\section{CONCLUSIONS}

Analysis of the experimental results permits the identification of two kinds of resource. The first, probably made up of labile compounds containing detritus, shows a higher global oxygen uptake during mineralisation. The second group basically comprises resources with refracting characteristics. When the uptake rates are considered, however, it is apparent that the 
mineralised parts of the substrates thought of as refracting can be easier to process than the labile fractions of the less refracting resources. An example is provided by comparing the DO uptake and the mineralisation rates of the Wolffia sp. with those of humic substances.

Acknowledgments - The authors thank Fundação de Amparo à Pesquisa do Estado de São Paulo (FAPESP) for financing this study (Process n. 91/1303-3) and Dr. Osvaldo N. Oliveira Jr. (IFSC-USP) for proofreading the manuscript.

\section{REFERENCES}

ANTONIO, R. M., 1992, Estimativa da capacidade heterotrófica em ecossistemas aquáticos. Monografia de Graduação, DHB, UFSCar.

CHAPRA, S. C. \& RECKHOW, K. H., 1983, Engineering approaches for lake management. Mechanistic Modeling. Butterworth/Ann Arbor. Woburn, v. 2, 492p.

DAVIS, M. L. \& CORNWELL, D. A., 1991, Introduction to environmental engineering. McGraw-Hill, New York, 822p.
JØRGENSEN, S. E., 1986, Fundamentals of ecological modelling. Developments in Environmental Modelling, 9. Elsevier, Amsterdam, 389p.

RAMANATHAN, M. \& GAUDY Jr., A. F., 1972, Studies on sludge yield in aerobic systems. J. Water. Pollut. Control Fed., 44: 441-450.

STEVENSON, F. J., 1982, Humus chemistry. Wiley, New York, 443p.

STREETER, H. W. \& PHELPS, E. B., 1925, A study of the pollution and natural purification of the Ohio river. U.S. Public Health Service Bulletin, 146.

STUMM, W. \& MORGAN, J. J., 1981, Aquatic chemistry. Wiley/Interscience, New York, 780p.

SWIFT, M. J., HEAL, D. W. \& ANDERSON, J. M., 1979, Studies in ecology: decomposition in terrestrial ecosystems. Blackwell, Oxford, 371p.

THURMAN, E. M., 1985, Organic geochemistry of natural waters. Nijhoff/Junk Po., Netherlands, 497p.

WESTLAKE, D. F., 1963, Comparations of plants productivity. Biol. Rev., 38: 385-425.

WETZEL, 1983, Limnology. Saunders, Philadelphia, 767p. 